\section{SMEs' competitiveness and international trade in the era of Global Value Chains (GVCs) in Tanzania: An assessment and future challenges}

\author{
Competitividad de las PYMEs y el comercio internacional en la era de las \\ cadenas globales de valor (GVCs) en Tanzania: Análisis y desafíos \\ Francis Lwesya ${ }^{\mathrm{a}, *} \nabla$ (1) \\ a) Department of Business Administration and Management, University of Dodoma (Tanzania, United Republic of) \\ * Primary Contact: flwesya@yahoo.com (Francis Lwesya)
}

\begin{abstract}
International trade continues to play a crucial role in economic transformation in African countries. The rise of Global Value Chains (GVCs) presents opportunities through which international trade can be effectively conducted. GVCs facilitate organization of trade, international production and investment by locating different stages of production process across varied countries. This presents opportunities to integrate Small and Medium Enterprises (SMEs) into global trading systems but also may generate challenges particularly to resource constrained SMEs. Reviewing the challenges for the participation in international trade and possible integration into GVCs by Tanzania's SMEs, the results show that the major challenges for SMEs internationalization are international marketing related constraints and global competition (69\%), supply side constraints (56\%), unfriendly investment climate (50\%) and financial constraints (37.5\%). As such, the role of trade policies remains critical in mitigating some of these challenges through formulating friendly legal and regulatory frameworks, enhancing SMEs productivity by building their managerial and technical capacities, minimizing trade costs, and increasing trade openness. However, given the current global, regional and domestic developments in Tanzania, trade policies need review so as to respond to the changing global trade landscape but also promote policy harmony, coherence and complementarities among varying implementing institutions, deficiency of which is debilitating policy implementation at present

Keywords: SMEs; global value chain (GVC); trade policies; international trade; SMEs competitiveness JEL Classification: F13; F14; F42; L26; M13

Resumen

El comercio internacional sigue desempeñando un papel crucial en la transformación económica de los países africanos. El auge de las cadenas globales de valor (GVCs) ofrece oportunidades para llevar a cabo el comercio internacional de forma más eficaz. Las GVCs facilitan la organización del comercio, la producción global y la inversión al situar las diferentes etapas del proceso de producción en diferentes países. Esto presenta oportunidades para integrar a las pequeñas y medianas empresas (PYMEs) en los sistemas de comercio mundial, pero también puede generar desafíos, especialmente para las PYMEs con recursos limitados. Al revisar los retos para la participación en el comercio internacional y la posible integración en las GVCs por parte de las PYMEs de Tanzania, los resultados muestran que los principales retos para la internacionalización de las PYMEs son las limitaciones relacionadas con el marketing internacional y la competencia global (69\%), las limitaciones del lado de la oferta (56\%), el clima de inversión poco favorable (50\%) y las limitaciones financieras (37,5\%). Por ello, el papel de las políticas comerciales sigue siendo fundamental para mitigar algunos de estos retos mediante la formulación de marcos legales y reglamentarios favorables, la mejora de la productividad de las PYMEs mediante el desarrollo de sus capacidades técnicas y de gestión, la minimización de los costes comerciales y el aumento de la apertura comercial. Sin embargo, dada la actual evolución mundial, regional y nacional de Tanzania, las políticas comerciales deben revisarse no sólo para responder al cambiante panorama del comercial mundial, sino que además deben promover la armonización, la coherencia y la complementariedad de las políticas entre las distintas instituciones de ejecución, dichas deficiencia están debilitando la implementación de las políticas en la actualidad.
\end{abstract}

Palabras clave: PYMEs; cadenas globales de valor (GVC); políticas comerciales; comercio internacional; competitividad de las PYMEs Clasificación JEL: F13; F14; F42; L26; M13 


\section{Introduction}

Small and Medium Enterprises (SMEs) are recognized across the globe to be important in nurturing entrepreneurial culture, employment creation, reducing poverty and play a critical role in the contribution to Gross Domestic Product (GDP) both in advanced countries as well as developing countries (Abor \& Quartey, 2010). This realization has led many countries including African countries to implement various policies and strategies which aim to promote SMEs development (Kongolo, 2010; Obeng \& Blundel, 2015). However, SMEs are still facing a number of challenges and constraints which limit their contribution to economic transformation in African countries. In most African countries SMEs experience more or less similar challenges including shortage of funds for business start up and operations, inadequate entrepreneurial skills, lack of information on market opportunities, inadequate Government departments' support, and limited access to relevant and appropriate technology (Singh \& Belwal, 2008). Nonetheless, the prevalence of these challenges and constraints is linked to policy failure in African countries (Mambula, 2002; Richardson et al., 2004; Tagoe et al., 2005; Storey, 2005; Singh \& Belwal, 2008). It is believed that necessity driven policies and regulatory reforms can play a critical role in the promotion of SMEs sector in developing countries, since SMEs that are supported by appropriate Government driven policies improve productivity and competitiveness thereby leading to more employment opportunities and economic growth (EBRD, 2004).

One of the pathways for achieving SMEs competitiveness is through their participation in international trade. Participation in international trade allows SMEs to learn by doing, get exposed to quality standards, superior technology and stiff competition (ITC, 2015). Moreover, the current changes in a global trading landscape via globalization and the resulting emergence of Global Value Chains (GVCs) and digital economy provide another avenue through which SMEs can effectively participate in international trade (López González \& Sorescu, 2019). Global value chain entails locating different stages of production processes across varied countries. Firms or businesses aim to achieve efficiency in their production processes, as a result, they tend to disperse some of the activities involved in value chain such as product design, product production, marketing and distribution etc. in varied countries (international fragmentation of production). According to World Bank (2020), GVC encompasses value adding activities and fragmentation of stages involved in producing a product or service to meet the needs of consumers with at least two stages being located in different countries. On the other hand, digital economy signifies an economy that is based on digital technologies; it involves a wide range of activities including conducting trade and marketing using digital platforms. Kasap (2016) argues that digital economy facilitates SMEs to access markets and integrate them in global value chains by lowering costs and barriers thereby increasing their sales and exports.

GVCs and digital economy present opportunities to SMEs from African countries which if effectively and extensively explored can enhance their competitiveness in international trade. GVCs are particularly relevant for firms in low income countries because they allow engaging in export business by just supplying part of the required components to manufacture a product, brings innovation, and it is easier to acquire knowledge, skills and technology via interaction with chain actors (Stamm, 2004; Baldwin, 2012; OECD, 2013; Escaith, 2014; Cusolito et al., 2016). However, the benefits derived from participation in GVCs are not evenly distributed among SMEs in African countries; there are SMEs that benefits more, some do not benefit at all while others loose in GVCs. Limited financial resources, low technologies, high trading costs, inefficiency logistics and cumbersome regulations and supply side constraints are some of the reasons for low productivity of African SMEs in GVCs compared with their counterpart large firms. As a result, according to African Development Bank (AfDB) report, African economies share in GVCs stood at only 2.2 percent by 2014. Yet, participation in GVCs either through importing or exporting tends to improve SMEs performance. For example, importing enables SMEs to acquire inputs and technologies which help them to boost productivity and become more competitive, on the other hand exporting enables SMEs to access foreign markets, learn by doing, explore new opportunities and become more competitive (Melitz, 2003; Vogel \& Wagner, 2010; Bas \& Strauss-Kahn, 2014 and 2015; Wagner, 2012; Wagner, 2014; WTO, 2016; López González, 2017).

There is a renewed push and enthusiasm towards industrialization agenda by the current Government in Tanzania. This is due to the role that industrialization can play particularly in generation of more employment opportunities, increased access to technology, enhanced competitiveness of local firms and its role to GDP. One of the core drivers of the industrialization agenda are the SMEs. As such, creating a conducive business environment that enables SMEs to develop linkages and networks with large firms locally and penetrate into global markets are some the key issues addressed in this drive. Mkenda and Rand (2020) state that SMEs need to be nurtured in order to foster and boost their penetration in global markets, particularly in areas that Tanzania has the comparative advantage. Yet, Tanzania has a considerable share in regional value chains in areas like light manufacturing and agro-processing (Christopher, 2019). However, according to World Bank's Enterprise Survey Data for 2013, Mkenda and Rand (2020), Tanzanian SMEs' penetration in global markets is constrained, among others, by lack of internationally recognized quality certificates, inadequate use of technology licensed from foreign-owned companies, failure to use research and development (R\&D), limited integration with foreign companies, limited access to finance, electricity outages and numerous taxes. Increased participation of SMEs in GVC could address some of the challenges that SMEs are facing in global markets and will enhance Tanzania's presence in GVCs. To realize this, strong coordination and building of 
efficient linkages along the value chain, trade facilitation, removal of trade barriers and improving the competitiveness of the SMEs are few of the critical areas that need attention in order to foster the integration of SMEs into GVCs. As such, Mkenda and Rand (2020) emphasize on the role of targeted policies to facilitate the process of internationalization for SMEs in Tanzania. Moreover, Cusolito et al. (2016) argues that policies in developing countries need to take into account the current demands by promoting a friendly business environment that positions a country to attract local and foreign investment and enable it to derive social and economic benefits from GVC participation. Therefore, the main objective of the study was to review the challenges for SMEs internationalization and the role that trade policies can play in promoting the competitiveness of Tanzania's SMEs in International Trade in the era of GVCs. The paper contributes to the understanding of the global value chains for the SME participation in international trade. The specific objectives were:

- To assess the challenges and constraints which obstruct the participation of SMEs in international trade and their integration into GVCs

- To review the role of trade policies in fostering SMEs integration into GVCs

- To review the SMEs Development Policy of 2003 and the National Trade Policy of 2003 of Tanzania in light of the current GVCs demands and identify the missing elements.

The remainder of the paper is organized as follows: Section 2 describes the literature review. Section 3 presents results and discussions. Section 4 presents conclusion and policy implications.

\section{Literature Review}

\subsection{The Uppsala Model of Internationalization Process}

This article is premised on the argument that participation in international trade can be one of the sources of gaining competitive advantage to Small and Medium Enterprises (SMEs) in developing countries. This is supported by a number of theories such as the Resource-Based View (RBV) and the Uppsala Model of Internationalization Process. Competitiveness is possible by gaining the knowledge that a firm accumulates through international activities (Johanson \& Vahlne, 1977, 2009). Resource Based View (RBV) approach puts prominence on firm's resources as one of the critical factors for achieving competitive advantage and those resources must be valuable, rare, imperfect imitability and non-substitutability (Barney, 1991). Barney (1991) introduced three types of resources which are physical capital resources (physical, technological, plant and equipment), human capital resources (training, experience, insights), and organizational capital resources. All these resources have been instrumental in shaping the firms' internationalization process.

On the other hand, the Uppsala model of internationalization process was pioneered by Johanson and Vahlne (1977). To date it has been revised several times (Johanson \& Vahlne, 1992, 2002, 2006, 2009). The earlier postulation of the model were that firms in their internationalization processes incrementally increases their commitment on a foreign market by increasing their presence as time passes and knowledge of the market grows. Moreover, it argued that firms entered new markets with a low level of commitment and as their knowledge of the market increases, more resources would be invested. However, this perspective seems to be contradicting with the changing internationalization process (Johanson \& Vahlne, 1977, 2009). Unlike the previous Uppsala Model which was centered on market commitment and market knowledge, the revised version of the Uppsala Model (2009) argues that internationalization process takes place within the firm's network position and where there is knowledge about the foreign market which is critical to recognize opportunities (Figure 1).

The model separates state and change variables each is divided into two aspects. The state variable considers aspects that are temporarily fixed by its nature. With regard to the Change-side, in the original model, the change variables were commitment decisions and current decisions (Johanson \& Vahlne, 1977). In the new model, the word relationship has been added to commitment decision in order to clarify that it regards the firms' decisions of further commitment to relationships within a specific country (Johanson \& Vahlne, 2009). The new model further shows firm's learning, creating and trust-building as important variables in network formation.

The Network Theory that the new Uppsala Model of internationalization process advocates is a response to the rise of globalization and digital economy (Johanson \& Vahlne, 2009). Network formation is important for increasing the participation of SMEs from African countries in global trading system. This is because global production and distribution systems bring together diverse economic actors with complex regime of global corporate governance raising challenges to African SMEs to participate in these systems. As a result, Global Value Chains (GVCs) and global production networks (GPNs) have been particularly useful to understand SMEs' global market engagements (Neilson et al., 2014). 
Figure 1. Uppsala Internationalization Process Model

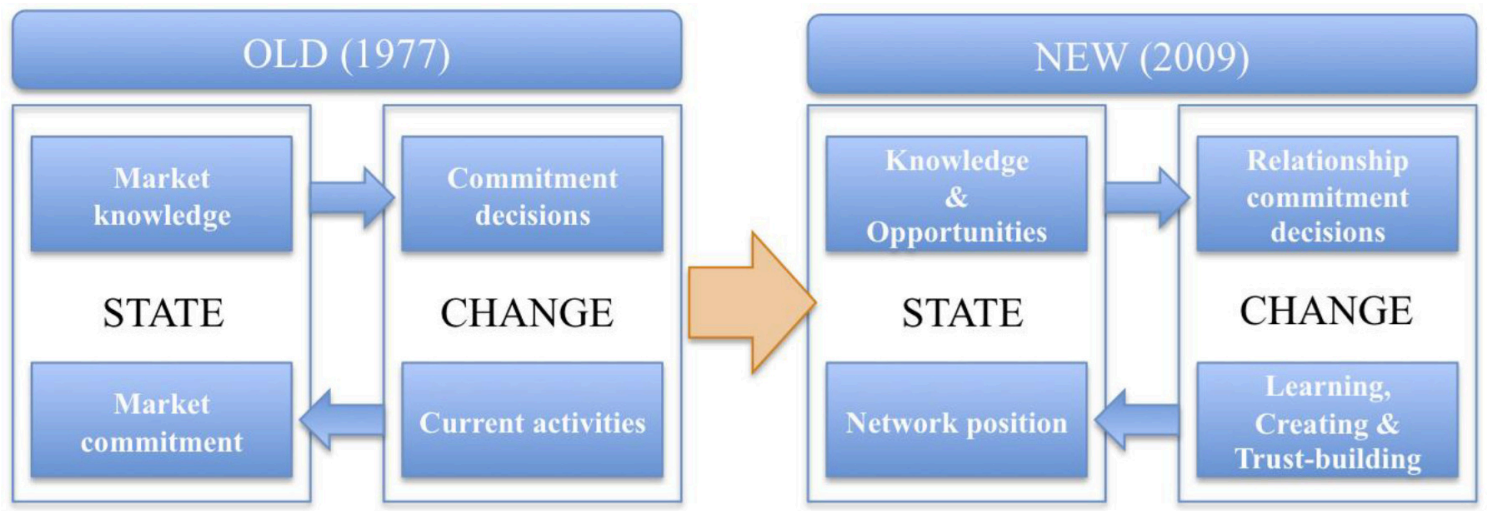

Source: Adapted from Tykesson and Alserud (2011)

\subsection{Drivers of Global Value Chains (GVCs) in Africa}

GVC encompasses value adding activities and fragmentation of stages involved in producing a product or service to meet the needs of consumers with at least two stages being located in different countries (World Bank, 2020). Businesses aim to achieve efficiency in their production processes, as a result, they tend to disperse some of their value chain activities across countries. Greater engagement in GVCs is seen as a central feature in the process of structural transformation particularly in developing countries. In African context, GVC is of particular relevance in order to foster industrialization, technology upgrading, export diversification and inclusive growth. Firms or businesses from Africa can be part of GVCs by performing one or both of the activities along the global value chain, the activities might be related to farming, extraction of resources, product design, management, marketing, distribution, post-sale services, product research and development, processing etc. According to UNCTAD (2013) promoting participation in GVCs is increasingly embraced by Governments and policy makers in African countries as one of the channels towards the path of structural transformation and economic development. GVCs facilitate the movement of resources across sectors and in different countries in a rational way (World Bank, 2020). As a result, in the process GVCs contribute towards industrial upgrading, exportation, employment and income generation, GDP growth and exploitation of other opportunities along the value chain. However, the participation in GVCs is not risk free or free from challenges, this is because income generation and other opportunities may as well be hindered by low productive capacities, inadequate technology and lack of the needed skills set (UNCTAD, 2013). Therefore, it is the role of policy makers to identify and implement policies that foster rather than discourage the participation of African businesses into GVCs.

The realization of the importance of GVCs in Africa can be seen in various initiatives which are implemented so as to facilitate the integration of African firms or businesses into GVCs at continental level. For example, regional bodies such as the East African Community (EAC) and Southern Africa Development Community (SADC) are pushing for the development and upgrading of Regional Value Chains (RVCs) which are important for enhancing production capacities and increasing competitiveness of SMEs at regional levels and serve as a stepping stone into global value chains. Effective participation in GVC, however, for African countries is dependent upon factors such as available resources, market size, infrastructures and the quality of institutions. Hence, the World Bank (2020) and Zeidy (2020) have listed critical drivers for Africa's participation in GVC which include the following:

- Factor endowments. Resources in form of financial resources, human resources and physical resources are important for GVCs participation. Countries that are bestowed with an abundance of natural resources enable GVC participation. Countries that have put in place favorable business environment tend to attract a lot of Foreign Direct Investments (FDIs), whether resource-seeking, market seeking or efficiency-seeking. This enables a country to acquire capital, technology and quality human resource which are important for GVCs integration.

- Market. The population of a country or regional bloc is one of the determinants of the GVCs integration. However, small developing countries are more dependent on imported products or inputs from foreign countries. In this respect trade openness (liberalization) can expand the size of the country market and help to bring about global competition which in turn leads to SMEs competitiveness.

- Geography. This refers to countries' connectivity through transport logistics. It is concerned with putting in place trade facilitation mechanisms by improving connectivity. In this respect remoteness will be overcome, strengthening and improving transport systems will improve connectivity and facilitate movement of products across borders. 
- Institutional Quality. The quality of institutions is important for the integration in GVCs, this is for the reason that institutions formulate various policies, laws and regulations which may foster or distort trade. However, on the other hand, Zeidy (2020) argues that regional integration can help strengthen institutional quality through friendly legal and regulatory rules, harmonized customs processes and procedures, and intellectual property rights protection which are important in international trade and GVCs integration.

In this perspective, the role of policies is critical to nurture SMEs' participation in GVCs. Zeidy (2020) argues that the right package of policies can stimulate the Africa's participation in GVC. However, Africa's share in GVCs is $3 \%$ of global trade in intermediate goods (Zeidy, 2020). Nonetheless, Africa has recorded some success stories; currently Africa's high shares in GVCs are inputs for other countries' exports, particularly in agriculture and natural resources of African exports (Table 1). According to Zeidy (2020) GVC participation in some of the Sub-Saharan African countries (Ethiopia, Kenya, South Africa, and Tanzania) grew by 10 percentage points or more, approaching what Poland or Vietnam now success stories.

Table 1. Participation in GVCs for selected African countries

\begin{tabular}{|c|l|l|}
\hline N & \multicolumn{2}{|c|}{ Sector/Product of GVC Participation } \\
\hline 1 & $\begin{array}{l}\text { Apparel, Food, Automotive industries and } \\
\text { business services }\end{array}$ & North and Sub-Saharan Africa \\
\hline 2 & Oil and other natural resources & $\begin{array}{l}\text { Democratic Republic of Congo, Botswana and } \\
\text { Nigeria }\end{array}$ \\
\hline 3 & Agribusiness and Apparel & Kenya and Ethiopia \\
\hline 4 & Manufacturing, Transport and Tourism & Tanzania \\
\hline 5 & Automotive industries & Morocco \\
\hline Source: Adapted from Zeidy (2020) & \\
\hline
\end{tabular}

\subsection{SMEs in Tanzanian Economy}

SME is perceived and defined differently across countries by taking into account the policies, programmes and role of the SME sector in the economy (Oladimeji et al., 2017). In Tanzania, SME is defined using the yardsticks like the number of employees, the capital invested in form of machinery, as well as turnover as indicated in Table 2.

Table 2. SME Definition in Tanzania

\begin{tabular}{|l|l|c|l|}
\hline $\mathbf{N}$ & \multicolumn{1}{|c|}{ Category } & Employees & \multicolumn{1}{c|}{ Capital Invested in Machinery (Tshs) } \\
\hline 1 & Micro enterprise & $1-4$ & Up to 5 mil. \\
\hline 2 & Small enterprise & $5-49$ & Above 5 mil. To 200 mil. \\
\hline 3 & Medium enterprise & $50-99$ & Above 200 mil. To 800 mil. \\
\hline 4 & Large enterprise & 100 and above & Above 800 mil \\
\hline
\end{tabular}

The SMEs sector in Tanzania is one of the major sources of employment opportunities after agriculture. Its contribution to employment is between (20-30\%) of the total country population and in terms of the SMEs contribution to GDP is estimated to be between (35-40\%) of the GDP (Finseth, 1998). As a result, promoting SMEs competitiveness is essential if Tanzania is to raise the contribution of SMEs particularly in job creation, innovation, income generation and economic development. However, since in general most of the SMEs are less productive compared with large firms, ITC (2018) identify four areas that have the potential for increasing African SMEs competitiveness in trade. These are:

- Enabling SMEs meet international standards. Failure to meet international standards is one of the constraints for SMEs to penetrate in international markets and receive certifications. Certification is a signal of offering high quality products and therefore competitiveness.

- Quality of infrastructure and logistic facilities. Good physical infrastructure such as roads, telecommunication, ICT, the supply of electricity and water etc are important for investment decisions.

- Human capital requirements. The quality of human resource is important for enhancing SMEs competitiveness. Business training and management skills, and the level of entrepreneurship skills are critical factors which are taken into account when making investment decisions. Therefore, shortage of people with the relevant expertise is one of the reasons for the low level of SMEs competitiveness in African countries.

- SMEs ability to access finance. Limited access to finance is of the challenges facing African SMEs and thereby lowering their competitiveness. This is in part driven by high interest rates, large collateral requirements and a burdensome application process. It is particularly challenging for women to obtain 
financing, as fewer African women have bank accounts, compared to men, and the legal rights of family capital and collateral can be restrictive, given local laws and customs about land ownership (ITC, 2018).

In view of these factors, the support of government, SMEs owners and managers are paramount in nurturing SMEs competitiveness. The government must provide direct support to SMEs and as well as improve the investment climate by formulating friendly policies and strategies for SMEs development. Another important role of the government is addressing the supply side constraints by putting in place quality infrastructure, trade facilitation measures, human capital development programmes, access to finance modalities etc. Participation in international trade is another avenue through which SMEs can enhance their competitiveness. According to ITC $(2015 ; 2018)$, SMEs that are engaging in world international trade become more competitive and the evidence suggests that SME exporters grow $4 \%$ faster than non-exporters. As such, since 2008 Tanzania initiated a strategy for improving trade competitiveness (Tanzania Trade and Competitiveness Strategy - TTIS). The strategy set three priorities, including expansion of existing exports to new and dynamic markets, integration of Tanzania into global production network, and lowering of the cost of doing business. Moreover in 2018 the Government launched a blue print for regulatory reforms to help improve the business environment in Tanzania. A blue print puts in place a framework for addressing business challenges and constraints. However, the export share of Tanzania in global exports for the past 10 years show mixed trend (Figure 2). The instability in export share suggests the need for more SMEs to penetrate in global markets and into GVCs (Mkenda \& Rand, 2020).

Figure 2. Tanzania's Export Share in Global Exports, 2001-2018

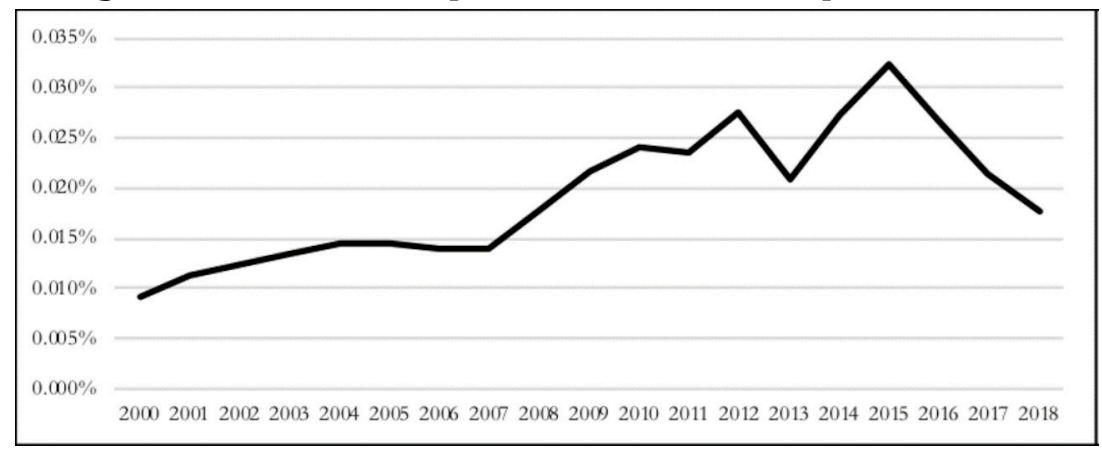

Source: Adapted from Mkenda and Rand (2020)

With regard to the regional integration, Tanzania is a member of East African Community (EAC) and Southern Africa Development Community (SADC) regions. EAC and SADC recognize the importance of regional value chains in accelerating trade among member states. However, to foster increased participation in regional value chains, lowering of trade costs, improving customs management and increasing transparency in rules of origin as products cross borders are critical issues (EAC, 2018). Tanzania's major exports were gold, coffee, tobacco, cashew nuts, pigeon peas, fish and horticultural products in 2018 and the major trading partners were China, India, South Africa, Kenya and UAE. Tanzania intra-EAC trade increased US\$ 707.7 million in 2017 to US\$ 811.3 million in 2018. Studies have indicated that countries that are more open to the rest of the world are better placed to absorb the rapid technological advances of leading nations. If the costs of technological imitation are lower than the costs of internally developed innovations, then a poorer country will grow faster than a more developed one. This faster rate of growth will continue so long as that country remains open to capturing new ideas until an equilibrium point, where the rate of growth becomes low. Moreover, the argument that poorer economies grow faster than the rich economies is in line with the convergence theory. Trade openness measured in either way, trade policies (tariff and non-tariff barriers) or as an outcome (the ratio of imports and exports over GDP) facilitates convergence through specializations and promotion of competition and technology transfer. However, liberalization alone does not automatically produce export dynamism or fast growth of incomes. But complementary policies and regulations are essential; this entails macroeconomic policies, property rights, governance (investment climate), infrastructure, education and training together with effective safety nets for those who disproportionately bear the costs of adjustment (Dollar \& Kraay, 2002). This suggests that a national trade policy should ensure harmony, coherence and complementarities with other sector policies. In fact, all other sector specific policies including the National Trade Policy should be drawn from a broad national development policy.

\subsection{Challenges and constraints hindering the participation of SMEs in International Trade in Tanzania}

SMEs in Tanzania face several constraints and challenges which impede their participation in international trade. Various studies have supported that poor infrastructures, supply capacity constraints, inadequate government support, lack of access to finance, unfriendly investment climate, inadequate skills and knowledge of the foreign market, inadequate business training and skills (entrepreneurial skills), intensive global 
competition and lack of knowledge on international marketing regulations and standards are among the challenges which hinder the participation and lower the competitiveness of Tanzanian SMEs in international trade (Table 3).

Table 3. Challenges facing SMEs in International Trade in Tanzania

\begin{tabular}{|l|cc}
\hline $\mathbf{N}$ & Researcher & Title Challenge
\end{tabular}

1 Rutashobya and Small firms' internationalization for Jaensson (2004) development in Tanzania Exploring the network phenomenon

2 Mhando (2009) Enhancing Tanzania's Export Performance through Effective Export Promotion and Support Services

3 Anderson Internationalization Opportunities and Inadequate international business skills, unawareness of existing export (2011) Challenges for Small and Medium-Sized promotion programmes, poor access to finance, and imperfect foreign Enterprises from Developing Countries market information.

4 Crick et al. $\quad$ A study into the international (2011) competitiveness of low and high intensity Tanzanian exporting SMEs

Limited education and training to SMEs E.g. technology and business capabilities.

Poor infrastructure, ineffective export promotion programmes and inefficient export support services.

5 Aikaeli (2012) $\quad$ Improving Competitiveness for SMEs to Investment climate impediments, inadequate innovation, poor Harness Available Trade and Investment infrastructure and high transactions cost, information asymmetry, Opportunities: The Case of Tanzania shortages and/or insufficient supply of factors of production and the poor economies of scale and scope.

6 Milanzi (2012) $\quad$ The Impact of Barriers on Export Behavior of a Developing Country Firms Evidence from Tanzania

Lack of export market knowledge and information, export supply capacity and poor infrastructure.

7 Mori and $\quad$ The role of the internet in overcoming Munisi (2012) information barriers: Implications for Exporting SMEs of the East African Community

8 Mbago (2013) The Constraints Faced by Tanzania SMEs in Exploitation of the Regional Markets. Case of Selected SMEs at Ilala Municipality

9 Lugome (2013) Impact of Trade Liberalization towards SMEs development: A Case Study of Morogoro Municipality

10 Kazimoto Assessment of Challenges facing Small (2014) and Medium Enterprises towards International Marketing Standards: a Case Study of Arusha Region Tanzania

11 ESRF (2016) $\quad$ Promoting the Participation of Small and Medium Enterprises (SMEs) in

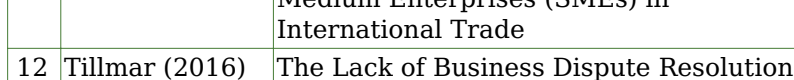

Lack of information to locate and analyze foreign market, inability to contact overseas customers, inability to identify foreign business opportunities, lack of product promotion and inadequate information

Lack of marketing skills, inability to market themselves, lack of international experience and lack of expertise.

Weak marketing and distribution capacity, lack of qualified human resources, vulnerability to external shocks due to global competition, lack of information technology hinders local SMEs to effectively compete Lack of government support to SMEs, lack of International marketing regulations and standards awareness, lack of consumer needs assessment, weak networking structures for the international marketing, and lack of skills for entrepreneurship. in East Africa: An Unresolved Impediment to SME Development?

13 Mpunga (2016) Examining the Factors Affecting Export Performance for Small and Medium Enterprises (SMEs) in Tanzania

Cumbersome business laws and regulations, un-conducive trade financing for SMEs, higher taxes charged on production and export, inadequate and instable financial capital, lack of appropriate production technology, ICT and information search competencies, low standard of products produced by the SMEs, restrictive entrance procedures into the country, price uncertainty in the export markets, product competition in the export market and complicated travel accreditation (passport/Visa).

14 Juma and Said SME Globalization-Tanzania Case Study (2016)

Legal and regulatory framework is bureaucratic, costly and centralized. Physical infrastructures including working premises, power, water supply, communication, warehouse, roads, and others, are poor. Inadequate business training and skills. Limited access to information and limited admission to technological developments partly due to lack of relevant information. Marketing difficulties on account of poor quality. Inadequate promotion skills and stiff competition. There is limited access to finance owing to lack of collateral, high costs of SMEs loans administration, and absence of dynamic SMEs credit windows.

15 Pasape (2018) Internationalization of Small and Medium Enterprises from Arusha Limited access to information, use of irrelevant market information and ineffective medium of communication. Limited sources of capital. Selling Tanzania: Market Information, Financial semi processed products and poor finished products and packaging Resources and Product Quality Setbacks materials as well as insufficient processing machinery.

16 Mkenda and Examining the Ability of Tanzanian Rand (2020) Small and Medium Enterprises (SMEs) to Increase their Penetration into Export
Markets

Limited access to finance, electricity outages and numerous taxes, lack of internationally recognized quality certificates, inadequate use of technology licensed from foreign-owned companies, failure to use research and development $(R \& D)$, limited integration with foreign companies. 


\section{Results}

\subsection{Constraints and challenges facing SMEs in International Trade}

According to the literature review in Table 3, the challenges which impede SMEs' participation in international trade can be grouped into the following themes:

- Theme 1. Unfriendly investment climate (UIC): Conducive business environment is critical for SMEs growth and their participation in international trade. Unfriendly business environment exhibited in form of lack of government support, poor policies and strategies, cumbersome legal and regulatory frameworks, numerous and higher taxes, restrictive entrance procedures into the country, complicated travel accreditation (passport/Visa) (Aikaeli, 2012; ESRF, 2016; Mpunga, 2016; Juma \& Said, 2016; Mkenda \& Rand, 2020) impede the growth and development of SMEs and therefore their international operations.

- Theme 2. Supply side constraints (SSC): These are trade related infrastructure such as physical infrastructures including roads, power, communication and ICT infrastructure, working premises, access to water supply, warehouses, appropriate and modern technology etc. Failure to address supply side constraints lead to high transaction costs which in turn lowers the competitiveness of SMEs both in local and international markets (Mhando, 2009; Crick et al., 2011; Milanzi, 2012; Aikaeli, 2012; ESRF, 2016; Juma \& Said, 2016; Pasape, 2018; Mkenda \& Rand, 2020). Moreover, Mkenda and Rand (2020) state that the low level of innovation and technological advancement in less developed countries is among the factors for the limited value addition of African SMEs products which in turn lower their penetration in international markets.

- Theme 3. Financial constraints (FC): limited access to financial resources limits SMEs capacity to exploit available opportunities and to participate in international operations. Juma and Said (2016) have indicated that collateral requirements, high costs of loans administration, and absence of SMEs credit windows are among the limitations for SMEs to access finance. Similarly, Pasape (2018) and Mkenda and Rand (2020) have shown that limited access to finance constrains SMEs to participate into global markets.

- Theme 4. Lack of business training and entrepreneurship skills (LBE): Business training and entrepreneurship skills are critical for the better performance of SMEs (Juma \& Said, 2016). Kotorri and Krasniqi (2018) argue that the more educated the managers are, the more likely they are to have better knowledge and problem solving capabilities, thereby, more likely to be associated with internationalization.

- Theme 5. International marketing related constraints and global competition (IMG): Factors such as lack of market information, low standard of products produced by the SMEs, lack of knowledge of marketing regulations and standards, lack of consumer needs assessment, weak marketing networking structures and high competition hamper SMEs internationalization (Mbago, 2013; Kazimoto, 2014). Others are lack of information to locate and analyze foreign market, inability to find foreign customers, inability to identify and explore foreign business opportunities, lack of product promotion and inadequate information (Mori \& Munisi, 2012).

Descriptive analysis was conducted to determine the frequency of the reviewed literature in Table 4 and Table 5.

Table 4. Challenges facing SMEs in International Trade in

\begin{tabular}{|c|l|c|c|c|c|c|}
\hline \multicolumn{1}{|c}{ Source } & \multicolumn{1}{c|}{ Tanzania } \\
\hline 1 & Rutashobya and Jaensson (2004) & & & & $\mathrm{X}$ & \\
\hline 2 & Mhando (2009) & $\mathrm{X}$ & $\mathrm{X}$ & & & \\
\hline 3 & Anderson (2011) & $\mathrm{X}$ & & $\mathrm{X}$ & & $\mathrm{X}$ \\
\hline 4 & Crick et al. (2011) & & $\mathrm{X}$ & & & $\mathrm{X}$ \\
\hline 5 & Aikaeli (2012) & $\mathrm{X}$ & $\mathrm{X}$ & & & $\mathrm{X}$ \\
\hline 6 & Milanzi (2012) & $\mathrm{X}$ & $\mathrm{X}$ & $\mathrm{X}$ & & $\mathrm{X}$ \\
\hline 7 & Mori and Munisi (2012) & & & & $\mathrm{X}$ & $\mathrm{X}$ \\
\hline 8 & Mbago (2013) & & & & & $\mathrm{X}$ \\
\hline 9 & Lugome (2013) & & & & $\mathrm{X}$ & $\mathrm{X}$ \\
\hline 10 & Kazimoto (2014) & $\mathrm{X}$ & $\mathrm{X}$ & & & $\mathrm{X}$ \\
\hline 11 & ESRF (2016) & & & \\
\hline
\end{tabular}


Table 4. Challenges facing SMEs in International Trade in

Tanzania

\begin{tabular}{|l|l|c|c|c|c|c|}
\hline N & \multicolumn{1}{|c|}{ Source } & UIC & SSC & FC & LBE & IMG \\
\hline 12 & Tillmar (2016) & & & $\mathrm{X}$ & $\mathrm{X}$ & \\
\hline 13 & Mpunga (2016) & $\mathrm{X}$ & $\mathrm{X}$ & $\mathrm{X}$ & & $\mathrm{X}$ \\
\hline 14 & Juma and Said (2016) & & $\mathrm{X}$ & $\mathrm{X}$ & $\mathrm{X}$ & $\mathrm{X}$ \\
\hline 15 & Pasape (2018) & $\mathrm{X}$ & $\mathrm{X}$ & & & \\
\hline 16 & Mkenda and Rand (2020) & & \\
\hline Source: Literature Review (2020)
\end{tabular}

Table 5. Challenges facing SMEs in International Trade in

Tanzania

\begin{tabular}{|c|c|c|}
\hline Variable & Frequency & Percentage (Frequency/literature*100) \\
\hline UIC & 8 & 50.0 \\
\hline SSC & 9 & 56.0 \\
\hline FC & 6 & 37.5 \\
\hline LBE & 5 & 31.3 \\
\hline IMG & 11 & 68.8 \\
\hline
\end{tabular}

The results in Table 5 suggest that internationalization of SMEs in Tanzania is mostly affected by international marketing related constraints and global competition (69\%), supply side constraints (56\%), unfriendly investment climate (50\%) and financial constraints (37.5\%).

\section{Conclusion and Policy Implications}

\subsection{Future Challenges}

\subsubsection{The Role of Trade Policies in fostering SMEs integration in GVCs}

SMEs may participate in GVCs through import and export trade. The import or export could be of inputs or outputs (Figure 3). According to Bas and Strauss-Kahn (2014) and López González (2017), import of inputs may help SMEs to develop export skills and capacity but also SMEs may acquire benefits in GVCs through Foreign Direct Investments (FDIs) and the operations of multinational enterprises in host countries (OECDUNIDO, 2019). However, when compared with large firms, SMEs face more challenges which may hinder their engagement in GVCs. In this context, trade policies can help tackle few of the challenges that SMEs face such as limited access to finance, high trade costs, limited access to market information and unleveled competition etc.

Figure 3. Framework for analyzing SME participation in GVCs

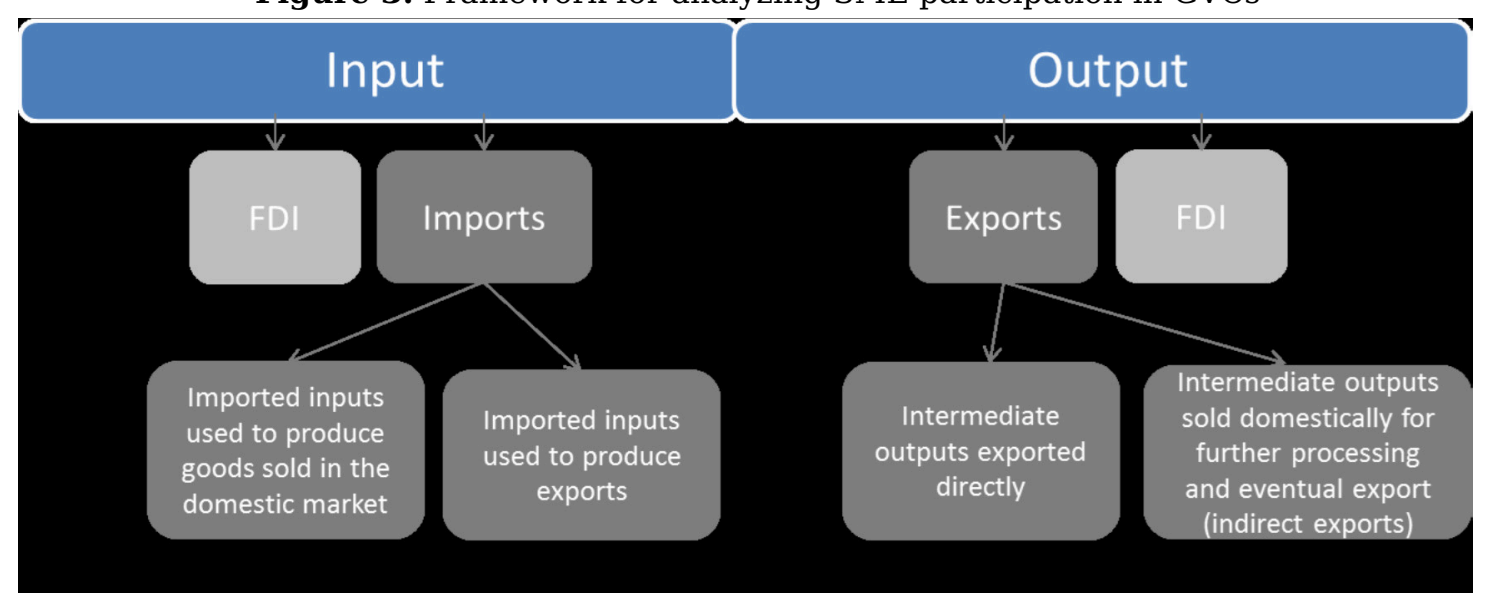

Source: Adapted from López González (2017)

A country's trade policies can play an important role to enhance SMEs' participation and integration in global trade. This will be evident when trade policies are designed in ways that foster and facilitate trade by helping SMEs innovate and get integrated into global value chains. The following are the key tenets that have to be addressed in trade policies in order to facilitate SMEs integration into the GVCs.

- Conducive Business Environment. A friendly policy environment must be in place in order to lower trade barriers. High trade costs related to importing and exporting when goods and services cross 
borders is one of barriers for SMEs participation in GVCs. A policy framework that focuses at lowering trade barriers will have an implication in reducing trade costs especially when they cross borders. This is because most of the SMEs have low absorptive capacity and cannot bear some of the costs compared to their counterpart large firms. Moreover, friendly business environment will stimulate Foreign Direct Investment (FDI) which is one of the channels for SMEs integration in the global economy. Promoting SMEs linkages with larger firms and multinationals can increase their indirect exports (López González et al., 2019). Therefore, friendly legal and regulatory reforms, tax laws, trade and investment policy reforms must be of supportive to the participation of SMEs in global value chain.

- Enhancing SMEs efficiency by building managerial and technical capacities of firms and increasing accessibility to capital and networks. SMEs are constrained by a wide range of factors which limit their competitiveness both in local and international markets. For-example in Tanzania, one of the major constraints for SMEs is limited access to finance. Addressing the problem of finance and other requirements for SMEs will stimulate their participation in GVCs. Like is the case with other African countries, most Tanzanian SMEs are still operating informally. The availability of an institutional framework and incentive package that promote access to capital and connectivity will enable most of the SMEs to graduate from informal to formal status which is one of the pre-requisites to SMEs participation in GVC. ITC (2018) argues that inefficient and fragile institutions contribute to the prevalence of informal activities.

- Imparting of managerial skills, better management practices and entrepreneurship skills. Provision of training to SMEs on managerial skills and better management practices is critical. For example, in Tanzania, SMEs participation in international trade is constrained by lack of entrepreneurship skills. Entrepreneurship skills are critical for the better performance of SMEs (Juma \& Said, 2016). Kotorri and Krasniqi (2018) argue that the more educated the managers are, the more likely they are to have better knowledge and problem solving capabilities, thereby, more likely to be associated with internationalization.

- Addressing supply side constraints. Trade policies must put in place an appropriate framework for addressing supply side constraints. These include trade related infrastructure such as physical infrastructures including roads, power, communication and ICT infrastructure, working premises, access to water supply, warehouses, appropriate and modern technology, logistics and other trade facilitation measures etc. Failure to address supply side constraints might lead to high transaction costs which in turn lowers the competitiveness of SMEs both in local and international markets (Mhando, 2009; Crick et al., 2011; Milanzi, 2012; Aikaeli, 2012; ESRF, 2016; Juma \& Said, 2016; Pasape, 2018; Mkenda \& Rand, 2020). Moreover, Mkenda and Rand (2020) state that the low level of innovation and technological advancement in less developed countries is among the factors for the limited value addition of African SMEs products which in turn lower their penetration in international markets. This calls for addressing supply-side constraints and trade development in an integrated manner.

- Increasing trade openness (trade liberalization). Policy framework that promotes trade liberalization is critical in increasing SMEs participation in GVCs. By adopting trade liberalization measures such as reducing or eliminating tariff and non-tariff barriers, simplifying rules of origin by adopting more flexible rules etc. It means a country is lowering trade constraints and therefore allowing more integration with the rest of the world. Lesson from Bangladesh's garment export industry suggests that the governments reviewed their trade policies to reduce barriers to trade for SMEs. As a result, duties were dropped on imports geared towards garment exports making garment industry more competitive.

- Addressing international marketing related constraints. In Tanzania, for-example, factors such as lack of market information, low standard of products produced by the SMEs, lack of knowledge of marketing regulations and standards, lack of consumer needs assessment, weak marketing networking structures and high competition hamper SMEs internationalization (Mbago, 2013; Kazimoto, 2014). Others are lack of information to locate and analyze foreign market, inability to find foreign customers, inability to identify and explore foreign business opportunities, lack of product promotion and inadequate information (Mori \& Munisi, 2012). Trade policies must address issues related to asymmetric information. Market information provided to SMEs got to be timely, easily accessible, accurate and reliable and put in place facilitating mechanisms through which SMEs will have to comply with international standards, identify foreign business opportunities and contact with overseas customers. In this context, the role of Government agencies is important and this needs to be reflected in trade policies.

- Minimizing trade costs. High trade costs stem from a number of factors such as poor infrastructure, applying rules of origin (ROOs), high tariffs, non-tariff barriers like cumbersome business licensing and registration procedures, delays in clearance procedures and difficult customs rules. Poor infrastructure and high tariffs may reduce SMEs competitiveness in GVCs since they increase costs of the final good 
(López González, 2017). Similarly, rules of origin (ROOs) may hinder SMEs participation in GVCs since ROOs are attached to a market under preferential arrangement (ADBI, 2014). On the other hand, while non-tariff barriers through for example import quotas and technical barriers may become a hindrance to SMEs, upon complying with the requirements they may acquire a competitive advantage and be able to integrate into GVCs (Cadot et al., 2018). As such, trade policies may address issues like adopting free trade arrangements (FTAs) and implementing trade facilitation measures. FTAs will help to minimize trade costs and will provide new market opportunities for SMEs. Trade facilitation measures, on the other hand, like simplifying business licensing and registration procedures, avoiding delays in clearance procedures and simplifying customs rules will minimize trade costs for SMEs and make them more competitive in markets (OECD, 2009).

\subsubsection{Trade Policies in light of GVCs demands and the missing elements in Tanzania}

Tanzania has formulated and implemented several trade policies and strategies which aim to position Tanzania's development path through reforms in its trade regime. One of the policies is the SME Development Policy of 2003 which was initiated to promote SMEs' growth and development in a bid to expand SMEs' contribution in the economy of Tanzania. The thrust behind SME Development Policy of 2003 was to increase new SMEs but also to advance performance and competitiveness of the existing SMEs. To achieve this, the policy puts in place strategies such as opening of SMEs tailored services in financial institutions and introducing innovative financial services, such as hire purchase schemes, and mobilizing resources to promote the development of new institutions for SME financing. One of the notable successes was the launching of the National Microfinance Bank (NMB) to cater for SMEs services. However, according Anderson (2011), one major policy weakness is in terms of institutional capacity and lack of clarity and focused coordination as there are many actors involved in SMEs development in Tanzania. Drawing from the experience of African countries, Olowu and Sako (2002), Ojimba (2012), Ndletyana (2013) and Odukoya (2013) argue that where multiple organizations are involved in policy implementation lead to difficulties in following up the impact of policies and assessing the implementation effectiveness. Bradley (2006) and O'Toole (2000) emphasize on the need for efficient structures that will guarantee cohesion and sustainability of policy implementation. As such, SMEs participation in GVCs might have been affected by lack of cohesion and coordination among various players involved in SMEs development. As a result, Mamman et al. (2019) indicate that the SMEs policy outcomes must take into account both the impact of the policy on the SMEs' achievement in a sustainable way and implementation drawbacks. Moreover, the SME Development Policy of 2003 is outdated given the various global, regional and domestic developments which have a direct effect on SMEs and trade in general.

In terms of the export sector, since 1980s Tanzania pursued outward oriented policy aiming to promote internationalization and export diversification. A series of reforms measures were introduced, this included devaluation of exchange rate, presidential export award, export credit guarantee scheme, seed capital revolving scheme, forex retention scheme, and trade facilitation measures. However, these measures worked against the promotion of exports since they were in favor of import substitution strategy while the strategy did not encourage exports, it increased the import bill since industries established needed to import machinery and spare parts from abroad. As a result, in 2003, the trade policy was formed. The trade policy of 2003 was aimed at raising efficiency and building a diversified competitive export sector as the means of stimulating higher rates of growth and development. To achieve this, the policy targeted to increase Tanzania's engagement in Multilateral Trading System (MTS), stimulate trade development so as to increase the capacity to endure intensifying competition within the domestic market. Moreover, it sets out mechanisms to stimulate value adding activities by attracting local and foreign investment as a means of increasing manufactured exports thereby increasing foreign earnings in areas in which Tanzania has a comparative advantage.

The national trade policy has instruments which are used to guide the direction of trade such as tariff and nontariff based measures, import licensing, pre-shipment inspection, and customs valuation, and export trade facilitation. However, the regional and international setting has also changed considerably since 2003 for the National Trade Policy of 2003 to be of significant relevance and helpful to SMEs in meeting the current GVCs demands. For example, the revival of the East African Cooperation (EAC) has also enabled the expansion of its membership from 3 to 6 after Rwanda, Burundi and South Sudan joined the three original EAC members, Kenya, Tanzania and Uganda in 2007. Moreover, there is move towards more regional integration, countries are advocating for Tripartite Free Trade Area (TFTA) which brings COMESA- SADC-EAC together as a major regional African trade and development initiative. In contrast, the National Trade Policy of 2003 does not aim explicitly at promoting regional trade blocs in general. This contradicts the current stance to include regional integration objective in the most recent sector or development policies. Secondly, although the policy objectives are broad (as should be), they are not consistent with the current regional integration strategy. This is a challenge to the Tanzanian SMEs since it may hinder their engagement in Regional Value Chains (RVCs) which are essential for enhancing production capacities and increasing competitiveness of SMEs at regional levels and serve as a stepping stone into global value chains (Zeidy, 2020). At the global level, countries are now embracing digital economy in trade which is facilitated by the ICT revolution especially "e-commerce". This was not so visible and apparent to Tanzania in 2003. However, in today's reality e-commerce has dominated global trade and Tanzania has to cope with this new development. 
Moreover, the focus of trade policy was on trade in goods, however, role and contribution of trade in services has increased substantially over the last decade. The policy does not recognize the growing role of trade in services and its increased linkage to other dynamics sectors. This may be a challenge to SMEs which are already participating in the GVCs, for example through the tourism sector. Like with the case of SME Development Policy of 2003, the Trade Policy of 2003 implementation is burdened with many players including ministries, departments and specialized institutions like Tanzania Trade Development Authority (TANTRADE), Fair Competition Commission (FCC), Tanzania Revenue Authority (TRA), Business Registrations and Licensing Agency (BRELA) etc. which are directly involved with trade. As a result, there is limited policy harmony, coherence and complementarities among varying implementing institutions which may have an impact on the SMEs competitiveness in GVCs. On the other hand, business environment is not conducive enough to foster the SMEs formalization process. The pace of SMEs formalization is slow, studies indicate that still a substantial number of SMEs are still operating informally; this is one of the constraints for their participation in GVCs. Trade policy review should ensure that necessary support is provided to formalize and ensure effective consultative mechanism to support small and medium enterprises to formalize and therefore be able to participate in GVCs and graduate into large exporting businesses. In light of the GVCs demands, the challenges face in the implementation of policies and the current changes in the global trade landscape, SME Development Policy of 2003 and the National Trade Policy of 2003 need review to contribute effectively towards the development of SMEs in Tanzania. This will be possible by identifying and promoting mechanisms to fast track legal and regulatory reform, particularly laws and regulations suffocating trade development in Tanzania. Enhancing coordination among implementing agencies, set feasible benchmark and ensure systematic monitoring and evaluation of the policy implementation and promoting policy ownership through aggressive awareness creation campaign and extensive involvement of broad stakeholders in all trade and trade related projects and programmes are some of the critical issues.

In concluding, GVCs present opportunities but also challenges for SMEs in Tanzania. GVCs may help integrate SMEs in global trading systems but also may present some challenges particularly to resource constrained SMEs which might lead to their exclusion from GVCs participation. The findings show that the participation in international trade and integration into GVCs for SMEs in Tanzania is hindered by international marketing related constraints and global competition (69\%), supply side constraints (56\%), unfriendly investment climate $(50 \%)$ and financial constraints (37.5\%). As such, the role of trade policies is critical in addressing some of the challenges that obstruct SMEs' participation in GVCs and international trade. However, given the current global, regional and domestic development in Tanzania, the SME Development Policy of 2003 and the Trade Policy of 2003 are outdated to cope with the current new realities and the changing global trading landscape. Moreover, implementation of these policies is fraught with weak coordination among the implementing agencies necessitating policy review to layout the framework that will promote policy harmony, coherence and complementarities among different implementing agencies. As such, the review of the policies must take into account areas like improving the business environment so as to fast tract the SMEs formalization process, enhancing SMEs productivity by building managerial and technical capacities of firms, easing accessibility to capital and promoting firms' networks, addressing international marketing related constraints, putting in place mechanisms for imparting of managerial skills, better management practices and entrepreneurship skills. Other areas include addressing supply side constraints, minimizing trade costs, and increasing trade openness as some of the pre-requisites to foster the participation in international trade and integration of SMEs into global value chains in Tanzania. 


\section{References}

Abor, J., \& Quartey, P. (2010). Issues in SME Development in Ghana and South Africa. International Research Journal of Finance and Economics, 39, 218-228

ADBI (2014). Trade Policy and Growth in Asia. https://hdl.handle.net/11540/1103

Aikaeli, J. (2012). Improving Competitiveness for SMEs to Harness Available Trade and Investment Opportunities: The Case of Tanzania. Huria: Journal of the Open University of Tanzania, 11, 25-43

Anderson, W. (2011). Internationalization Opportunities and Challenges for Small and Medium-Sized Enterprises from Developing Countries. Journal of African Business, 12(2), 198-217. https://doi.org/10.1080/15228916.2011.588912

Baldwin, R. (2012). Global supply chains: Why they emerged, why they matter, and where they are going CEPR Discussion Papers 9103

Barney, J. (1991). Firm Resources and Sustained Competitive Advantage. Journal of Management, 17(1), 99-120. https://doi.org/10.1177/014920639101700108

Bas, M., \& Strauss-Kahn, V. (2014). Does importing more inputs raise exports? Firm-level evidence from France. Review of World Economics, 150(2), 241-275. https://doi.org/10.1007/s10290-013-0175-0

Bas, M., \& Strauss-Kahn, V. (2015). Input-trade liberalization, export prices and quality upgrading. Journal of International Economics, 95(2), 250-262. https://doi.org/10.1016/j.jinteco.2014.12.005

Bradley, J. (2006). Evaluating the impact of European Union Cohesion policy in less-developed countries and regions. Regional Studies, 40(2), 189-200. https://doi.org/10.1080/00343400600600512

Cadot, O., Gourdon, J., \& van Tongeren, F. (2018). Estimating Ad Valorem Equivalents of Non-Tariff Measures: Combining Price-Based and Quantity-Based Approaches. . https://doi.org/10.1787/f3cd5bdc-en

Christopher, F. (2019). Tanzania and Global Value Chain. Citizen press. pp.4

Crick, D., Kaganda, G. E., \& Matlay, H. (2011). A study into the international competitiveness of low and high intensity Tanzanian exporting SMEs. Journal of Small Business and Enterprise Development, 18(3), 594-607. https://doi.org/10.1108/14626001111155727

Cusolito, A. P., Safadi, R., \& Taglioni, D. (2016). Inclusive Global Value Chains: Policy Options for Small and Medium Enterprises and Low-Income Countries. World Bank. https://doi.org/10.1596/978-1-4648-0842-5

Dollar, D., \& Kraay, A. (2002). Growth is Good for the Poor. Journal of Economic Growth, 7(3), 195-225. https://doi.org/10.1023/A:1020139631000

EAC (2018). EAC Trade \& Investment Report, 2018

EBRD (2004). SME Finance in the Early Transition Countries: The EBRD's Experience, European Bank of Reconstruction and Development. Annual report 2004

Escaith, H. (2014). Exploring the Policy Dimensions of Trade in Value-Added. SSRN Electronic Journal. https://doi.org/10.2139/ssrn.2522909

ESRF (2016). Participation of Small and Medium Enterprises (SMEs) in International Trade: Country updates. http://www.cuts-geneva.org/pacteac2/index.php/events/item/131-participation-of-small-and-mediumenterprises-smes-in-international-trade

Finseth, W. (1998). A Strategic Plan To Develop Tanzania's National Policy For Small Business. A consultancy report submitted to the ministry of industry and trade

ITC (2015). SME Competitiveness Outlook 2015: Connect, compete and change for inclusive growth

ITC (2018). Promoting SME Competitiveness in Africa: Data for de-risking investment

Johanson, J., \& Vahlne, J. (1977). The Internationalization Process of the Firm-A Model of Knowledge Development and Increasing Foreign Market Commitments. Journal of International Business Studies, 8(1), 23-32. https://doi.org/10.1057/palgrave.jibs.8490676

Johanson, J., \& Vahlne, J. (1990). The Mechanism of Internationalisation. International Marketing Review, 7(4). https://doi.org/10.1108/02651339010137414

Johanson, J., \& Vahlne, J. (1992). Management of foreign market entry. Scandinavian International Business Review, 1(3), 9-27. https://doi.org/10.1016/0962-9262(92)90008-T

Johanson, J., \& Vahlne, J. (2006). Commitment and opportunity development in the internationalization process: A note on the Uppsala internationalization process model. Management International Review, 46(2), 165-178. https://doi.org/10.1007/s11575-006-0043-4

Johanson, J., \& Vahlne, J. (2009). The Uppsala internationalization process model revisited: From liability of foreignness to liability of outsidership. Journal of International Business Studies, 40(9), 1411-1431. https://doi.org/10.1057/jibs.2009.24

Juma, S. A., \& Said, F. A. (2016). SME Globalization-Tanzania Case Study. International Journal Advances in Social Science and Humanities, 4(6)

Kasap, E. I. (2016). Digital Economy: Opportunities and Challenges for SME Development. Paper presented at 30th CACCI Conference 
Kazimoto, P. (2014). Assessment of Challenges facing Small and Medium Enterprises towards International Marketing Standards : a Case Study of Arusha Region Tanzania. International Journal of Academic Research in Accounting Finance and Management Sciences, 4(2), 303-311

Kongolo, M. (2010). Job creation versus job shedding and the role of SMEs in economic development. African Journal of Business Management, 4(11), 2288-2295

Kotorri, M., \& Krasniqi, B. A. (2018). Managerial Characteristics and Export Performance - Empirical Evidence from Kosovo. South East European Journal of Economics and Business, 13(2), 32-48. https://doi.org/10.2478/jeb-2018-0008

Lugome, B. A. (2013). Impact of trade liberalization towards SMes development in Tanzania: a case study of Morogoro municipality. (Doctoral dissertation).. Master of Business Administration (MBA-CM) of Mzumbe University

López González, J. (2017). Mapping the participation of ASEAN small- and medium- sized enterprises in global value chains. . https://doi.org/10.1787/2dc1751e-en

López González, J., \& Sorescu, S. (2019). Helping SMEs internationalise through trade facilitation. , 229. https://doi.org/10.1787/2050e6b0-en

López González, J., Munro, L., Gourdon, J., Mazzini, E., \& Andrenelli, A. (2019). Participation and benefits of SMEs in GVCs in Southeast Asia. . https://doi.org/10.1787/3f5f2618-en

Mambula, C. (2002). Perceptions of SME Growth Constraints in Nigeria. Journal of Small Business Management, 40(1), 58-65. https://doi.org/10.1111/1540-627X.00039

Mamman, A., Bawole, J., Agbebi, M., \& Alhassan, A. (2019). SME policy formulation and implementation in Africa: Unpacking assumptions as opportunity for research direction. Journal of Business Research, 97, 304-315. https://doi.org/10.1016/j.jbusres.2018.01.044

Mbago, A. (2013). The Constraints Faced by Tanzania SMEs in Exploitation of the Regional Markets. Case of Selected SMEs at Ilala Municipality. (Doctoral dissertation).. Business Administration (MBA-CM) of Mzumbe University

Melitz, M. J. (2003). The Impact of Trade on Intra-Industry Reallocations and Aggregate Industry Productivity. Econometrica, 71(6), 1695-1725. https://doi.org/10.1111/1468-0262.00467

Mhando, N. (2009). Enhancing Tanzania's Export Performance through Effective Export Promotion and Support Service. (Doctoral dissertation).. Master degree in Business Administration at KDI school of Public Policy and Management

Milanzi, M. (2012). The Impact of Barriers on Export Behavior of a Developing Country Firms: Evidence from Tanzania. International Journal of Business and Management, 7(3). https://doi.org/10.5539/ijbm.v7n3p10

Mkenda, B. K., \& Rand, J. (2020). Examining the Ability of Tanzanian Small and Medium Enterprises (SMEs) to Increase their Penetration into Export Markets. Business Management Review, 23(1), 9-102. https://bmr.udsm.ac.tz/index.php/bmr/article/view/120

Mori, N., \& Munisi, G. (2012). The Role of the Internet in Overcoming Information Barriers: Implications for Exporting SMEs of the East African Community. Journal of Entrepreneurship, Management and Innovation, 8(2), 60-77. https://doi.org/10.7341/2012824

Mpunga, H. S. (2016). Examining the Factors Affecting Export Performance for Small and Medium Enterprises (SMEs) in Tanzania. Journal of Economics and Sustainable Development, 7(6)

Ndletyana, M. (2013). Policy incoherence: a function of ideological contestations? In F. Nyamnjoh, U. Pillay, G. Hagg, \& J. Jansen (Eds.), State of the Nation: South Africa: 2012-2013 (pp. 51-71). HSRC Press

Neilson, J., Pritchard, B., \& Yeung, H. W. (2014). Global value chains and global production networks in the changing international political economy: An introduction. Review of International Political Economy, 21(1), 1-8. https://doi.org/10.1080/09692290.2013.873369

O'Toole, L. J. (2000). Research on Policy Implementation: Assessment and Prospects. Journal of Public Administration Research and Theory, 10(2), 263-288. https://doi.org/10.1093/oxfordjournals.jpart.a024270

Obeng, B. A., \& Blundel, R. K. (2015). Evaluating Enterprise Policy Interventions in Africa: A Critical Review of Ghanaian Small Business Support Services. Journal of Small Business Management, 53(2), 416-435. https://doi.org/10.1111/jsbm.12072

Odukoya, A. (2013). Corruption and Poverty in Africa. In M. Muchie, P. Lukhele-Olorunju, \& O. B. Akpor (Eds.), The African Union Ten Years After: Solving African Problems with Pan-Africanism and the African Renaissance. African Books Collective

OECD (2009). Top Barriers and Drivers to SME Internationalisation. Report by the OECD Working Party on SMEs and Entrepreneurship, OECD

OECD (2013). Financing SMEs and Entrepreneurs 2013: An OECD Scoreboard. OECD Publishing. https://doi.org/10.1787/fin_sme_ent-2013-en

OECD-UNIDO (2019). Integrating Southeast Asian SMEs in global value chains: Enabling linkages with foreign investors. https://www.oecd.org/investment/Integrating-Southeast-Asian-SMEs-in-global-value-chains.pdf 
Ojimba, D. P. (2012). Vocational and Technical Education in Nigeria : Issues, Problems and Prospects' Dimensions (IPP). Journal of Educational and Social Research, 2(9)

Oladimeji, M. S., Ebodaghe, A. T., \& Shobayo, P. B. (2017). Effect of Globalization on Small and Medium Enterprises (SMEs) Performance in Nigeria. International Journal of Entrepreneurial Knowledge, 5(2), 56-65. https://doi.org/10.1515/ijek-2017-0011

Olowu, D., \& Sako, S. (2002). Better Governance and Public Policy: Capacity Building for Democratic Renewal in Africa. Thomson-Shore

Pasape, L. (2018). Internationalization of Small and Medium Enterprises from Arusha Tanzania: Market Information, Financial Resources and Product Quality Setbacks. Business and Management Studies, 4(2), 77. https://doi.org/10.11114/bms.v4i2.3268

Richardson, P., Howarth, R., \& Finnegan, G. (2004). The challenges of growing small businesses: insights from women entrepreneurs in Africa. https://www.ilo.org/empent/Publications/WCMS_111395/lang-en/index.htm

Rutashobya, L., \& Jaensson, J. (2004). Small firms' internationalization for development in Tanzania. International Journal of Social Economics, 31(1/2), 159-172. https://doi.org/10.1108/03068290410515484

Singh, G., \& Belwal, R. (2008). Entrepreneurship and SMEs in Ethiopia: Evaluating the role, prospects and problems faced by women in this emergent sector. Gender in Management, 23(2). https://doi.org/10.1108/17542410810858321

Stamm, A. (2004). Value Chains for Development Policy: Challenges for Trade Policy and the Promotion of Economic Development, Concept Study. Deutsche Gesellschaft für Technische Zusammenarbeit (GTZ) $\mathrm{GmbH}$

Storey, D. J. (2005). Entrepreneurship, Small and Medium Sized Enterprises and Public Policies. In A. Zoltan J., \& A. David B. (Eds.), Handbook of Entrepreneurship Research. Springer. https://doi.org/10.1007/0-387-24519-7_18

Tagoe, N., Nyarko, E., \& Anuwa-Amarh, E. (2005). Financial Challenges Facing Urban SMEs under Financial Sector Liberalization in Ghana. Journal of Small Business Management, 43(3), 331-343. https://doi.org/10.1111/j.1540-627X.2005.00140.x

Tillmar, M. (2016). The Lack of Business Dispute Resolution in East Africa: An Unresolved Impediment to SME Development? In L. Achtenhagen, \& E. Brundin (Eds.), Entrepreneurship and SME Management Across Africa (pp. 51-64). Springer. https://doi.org/10.1007/978-981-10-1727-8_4

Tykesson, D., \& Alserud, M. (2011). The Uppsala Model 's Applicability on Internationalization Processes of European SMEs, Today - A Case Study of Three Small and Medium Sized Enterprises. (Doctoral dissertation).. Lunds Universitet

UNCTAD (2013). Global Value Chain and Development: Investment and Value Added Trade in Global Economy, A preliminary Analysis

Vahlne, J. -., \& Johanson, J. (2002). New technology, new business environments and new internationalization processes? In V. Havila, M. Forsgren, \& H. Hakansson (Eds.), Critical perspectives on internationalization (pp. 209-228). Pergamon

Vogel, A., \& Wagner, J. (2010). Higher productivity in importing German manufacturing firms: self-selection, learning from importing, or both? Review of World Economics, 145(4), 641-665. https://doi.org/10.1007/s10290-009-0031-4

Wagner, J. (2012). International trade and firm performance: a survey of empirical studies since 2006. Review of World Economics, 148(2), 235-267. https://doi.org/10.1007/s10290-011-0116-8

Wagner, J. (2014). Firm age and the margins of international trade: Comparable evidence from five European countries, Working Paper Series in Economics, No. 308. University of Lüneburg

World Bank (2020). World Development Report 2020: Trading for Development in the Age of Global Value Chains. World Bank. https://doi.org/10.1596/978-1-4648-1457-0

WTO (2016). Levelling the Trading Field for SMEs, World Trade Report 2016. WTO Publishing

Zeidy, I. A. (2020). Global Value Chain as a vehicle for Development in Africa. Implication of COVID 19 in the Future of Global Value Chain. Common Market for Eastern and Southern Africa 